\title{
Psychrotrophic bacteria in Brazilian organic dairy products: identification, production of deteriorating enzymes and biofilm formation
}

\author{
Cínthia Aparecida RABÊLO${ }^{1}$, Marina RICARDO ${ }^{1}$, Julia Assis PORFÍRIO ${ }^{1}$, Tatiana Colombo PIMENTEL ${ }^{2 *}$ (D), \\ Janaína dos Santos NASCIMENTO ${ }^{1}$, Leonardo Emanuel de Oliveira COSTA ${ }^{1}$
}

\begin{abstract}
The psychrotrophic bacteria count and the profile of Gram-negative bacteria present in commercial Brazilian organic dairy products (27 samples, pasteurized whole milk, Minas Frescal cheese, and yoghurt, equally distributed) as well as the biofilmproducing capacity and the production of deteriorating enzymes were investigated. Most of the samples (59\%) presented psychrotrophic bacteria counts higher than $4 \log \mathrm{CFU} / \mathrm{g}$, indicating problems in the microbiological quality of the products. The identification of Gram-negative bacteria revealed the presence of micro-organisms that can be potentially harmful (39.4\% Acinetobacter baumanii/calcoaceticus, 23.2\% Burkoderia pseudomallei, 10.1\% Halfnia alvei) and/or deteriorating microorganisms (6.1\% Pseudomonas aeruginosa) with the capacity of producing proteases (36.4\%), lecithinases (41.4\%), and lipases (4\%). Roughly, $68.7 \%$ of micro-organisms were non-producers of biofilms, $28.3 \%$ were medium biofilm producers, and $3.0 \%$ were high biofilm producers. The findings suggest there are problems related to the good practices of obtaining organic milk and in the manufacture of dairy products.
\end{abstract}

Keywords: organic dairy food; psychrotrophic bacteria; biofilm.

Practical Application: Few studies have evaluated milk and dairy products derived from organic production, and none of them focused on psychrotrophic bacteria. We observed that organic dairy products presented increased psychrotrophic counts indicating problems in the microbiological quality of the products, suggesting there are problems related to the handling, resulting in high counts of psychrotrophic bacteria with the capacity to produce deteriorating enzymes and, to a lesser extent, the formation of biofilms.

\section{Introduction}

Organic milk and dairy products have gained a significant visibility in the consumer market (Dolgopolova \& Roosen, 2018) as they are considered to have high nutritional value and are absent from intentional contaminants added during handling (Heckman, 2019).

Although psychrotrophic bacteria are sensitive to the heat treatment, they produce thermoresistant enzymes that degrade the milk constituents, alter sensory characteristics, and reduce the shelf life of dairy foods (Machado et al., 2017). The assessment of microbiological quality of raw milk from the conventional production system is already well known but the analysis of the organic system is lacking. Indeed, few studies have evaluated milk and dairy products derived from organic production (Kouřimská et al., 2014), and none of them focused on psychrotrophic bacteria.

In this aspect, this work aimed to evaluate the levels of psychrotrophic bacteria, and the profile of Gram-negative bacteria present in organic dairy products (pasteurized whole milk, Minas Frescal cheese, and yoghurt) marketed in Rio de Janeiro, Brazil.

\section{Materials and methods}

\subsection{Samples}

Different organic dairy-based products were analyzed in this work: pasteurized whole milk $(n=9)$, yoghurt $(n=$ $9)$, and Minas Frescal cheese $(n=9)$, totaling 27 samples. The samples were purchased in the local market (Rio de Janeiro, Brazil) and transported under refrigeration to the Laboratory of Microbiology of the Federal Institute of Education, Science and Technology of Rio de Janeiro (IFRJ). The analyzes were performed up to $24 \mathrm{~h}$ after the acquisition of the samples. It is noteworthy that the sample size, i.e., number of organic products, was related to the products available in the marketplace in 2017.

\subsection{Psychrotrophic micro-organisms: isolation, and identification}

The quantification of psychrotrophic micro-organisms was performed according to the methodology proposed by Mastromatteo et al. (2010). Samples were weighed and serial dilutions were performed in peptone water. Then, samples were inoculated by the surface inoculation method using Plate Count Agar (PCA) supplemented with triphenyltetrazolium 
(1\%). After plating, the plates were incubated at $7^{\circ} \mathrm{C}$ for 10 days. After the incubation period, the colonies were counted and isolated.

Psychrotrophic bacteria isolates were purified using TSA agar. After this step, Gram staining, oxidase test (Laborclin, Pinhais, Paraná) and the identification with the Bactray I, II, and III Kit (Laborclin, Pinhais, Paraná) were carried out. In addition, the isolates were identified based on their $16 \mathrm{~S}$ rRNA gene sequences using the Basic local alignment search tool in accordance with recent study (Hahne et al., 2019). The isolates were deposited in the Culture Collection of the Laboratory of Microbiology of the IFRJ.

\subsection{Extracellular enzymes: evaluation of production capacity}

The production capacity of proteases, lipases, and lecithinases was evaluated according to the methodology proposed by Dogan \& Boor (2003) and Bates \& Liu (1963). For the proteases production analysis, the isolates were inoculated in Skim Milk Agar and incubated at $7^{\circ} \mathrm{C}$ for 10 days. For the lipolytic activity analysis, the isolates were inoculated in modified Spirit Blue Agar and incubated at $37^{\circ} \mathrm{C}$ for 5 days. For the lecithinase production evaluation, PCA Agar supplemented with 50\% (v/v) egg yolk solution was used. The isolates were inoculated and incubated at $7^{\circ} \mathrm{C}$ for 10 days. The evaluation of the enzymatic activity was determined by the presence of halo hydrolysis.

\subsection{Biofilm formation}

For the assessment of biofilm-producing capacity, the methodology proposed by Stepanovic et al. (2000) was used. The isolates were inoculated in BHI Agar and incubated at $28^{\circ} \mathrm{C}$ for $48 \mathrm{~h}$. Then, an aliquot $(200 \mu \mathrm{L})$ was transferred, in quadruplicate, to 96 -well plates. The microplates were incubated at $37^{\circ} \mathrm{C}$ for $24 \mathrm{~h}$ under agitation $(100 \mathrm{rpm})$. After incubation, the culture was removed from the wells and each well was washed 3 times with sterile distilled water, dried at $37^{\circ} \mathrm{C}$ for $20 \mathrm{~min}$ and added with $100 \mu \mathrm{L}$ of absolute ethanol for $15 \mathrm{~min}$. After removing the ethanol, violet crystal $(100 \mu \mathrm{L}$ at $0.25 \% \mathrm{w} / \mathrm{v})$ was added and let react for $10 \mathrm{~min}$. The dye was removed, the plates were washed with sterile distilled water, dried and added with $200 \mu \mathrm{L}$ of $80 \%$ (v/v) glacial acetic acid. Biofilm formation was evaluated by spectrophotometry $(\lambda=600 \mathrm{~nm})$. Staphylococcus aureus ATCC 12600 was used as a positive control and sterile BHI broth was used as a negative control. The biofilm-producing capacity was analyzed by comparing the absorbances of the negative control with the absorbances of the isolates, in a way that the isolates were classified as non, low, medium, and high biofilm formers.

\section{Results and discussion}

\subsection{Characterization of organic milk and derived products}

Only $3(11 \%)$ of the 27 samples analyzed did not contain the organic certification seal or any other type of proof of the organic origin of the product. Twelve samples (44\%) presented incomplete information regarding the list of ingredients, nutritional table and means of conservation. The demand for organic products, especially milk and processed dairy foods, has increased considerably in the last years. Accordingly, the market for organic products tends to grow from 10 to $30 \%$ per year worldwide (Lu et al., 2010, Willer \& Kilcher, 2011; Bee Lian et al., 2016).

This trend is associated with consumers' perception that these products are of better quality than the conventional counterparts and may present possible health benefits. Additionally, the motivation for sustainable issues and animal welfare concerns also plays a role (Schwendel et al., 2015). The certification of the organic system is the instrument that guarantees compliance with strict guidelines to produce organic foods. Herein, it is possible to observe that the majority of the products (89\%) evaluated in the present study were certified as organic.

\subsection{Psychrotrophic micro-organisms counts}

Table 1 shows the counts of psychrotrophic bacteria for the organic dairy products. The counts ranged from $<1$ to $6.54 \log \mathrm{CFU} / \mathrm{g}$ in pasteurized whole milk samples, from 4.40 to $6.48 \log \mathrm{CFU} / \mathrm{g}$ in Minas Frescal cheeses, and from $<1$ to $4.61 \mathrm{log} \mathrm{CFU} / \mathrm{g}$ in yogurts. The pasteurized whole milk from producer B (three samples) showed counts below the limit of detection $(<1 \log \mathrm{CFU} / \mathrm{g})$. A sample from producer $\mathrm{C}$ also showed counts below the limit of detection. The results show that producer B has the product with the best microbiological quality. This result may be associated to the application of Good Manufacturing Practices (GMP) in the industrial processes and in manufacturing steps, ensuring the quality of products by its implementation at root levels.

The count of psychrotrophic bacteria in raw milk is influenced by hygiene conditions at milking, length of storage period, and storage temperature. Long-term storage favors the development of these bacteria and inhibits the development of mesophilic bacteria (Samaržija et al., 2012). As psychrotrophic bacteria are sensitive to heat treatments, some authors report that the contamination of milk and other dairy foods by psychrotrophic bacteria is associated with post-pasteurization contamination (Van Tassell et al., 2012). Brazilian legislation recommends that raw milk must be refrigerated after milking; however, it does not establish standards for counting of psychrotrophic bacteria.

All Minas Frescal cheese samples presented psychrotrophic bacteria counts higher than $4.00 \log \mathrm{CFU} / \mathrm{g}$, regardless of their origin. For yogurts, a sample from each producer presented counts below the limit of detection. The quality, stability, and yield of dairy foods, such as cheeses and yogurts, are directly related to the microbiological quality of the raw milk, especially with regard to the counts of psychrotrophic micro-organisms (Samaržija et al., 2012). Therefore, it is obvious that raw materials with a high initial count of psychrotrophic micro-organisms compromise the quality of processed products. The quality impairment is related to the presence of thermoresistant enzymes produced by psychrotrophic micro-organisms that alter the quality of milk (Samaržija et al., 2012; Hanamant \& Bansilal, 2013; Decimo et al., 2014; Machado et al., 2017).

Seven $(25.9 \%)$ of the 27 samples analyzed presented a psychrotrophic bacteria count greater than or equal to $6 \log$ CFU/g. Therefore, more than $1 / 4$ of the products presented low microbiological condition ( $>6$ log CFU psychrotrophic 
Table 1. Psychrotrophic microorganisms counts in Brazilian organic dairy foods.

\begin{tabular}{|c|c|c|c|c|}
\hline Sample & $\log$ UFC & $\begin{array}{c}\text { Numbe of } \\
\text { isolates }\end{array}$ & Dairy food & Producer \\
\hline 1 & 5.75 & 7 & milk & A \\
\hline 2 & $6.00^{\dagger}$ & 17 & milk & A \\
\hline 3 & 5.87 & 12 & milk & A \\
\hline 4 & $<2.00$ & * & milk & B \\
\hline 5 & $<2.00$ & * & milk & B \\
\hline 6 & $<2.00$ & * & milk & B \\
\hline 7 & $6.48^{\dagger}$ & 17 & milk & $\mathrm{C}$ \\
\hline 8 & $<2.00$ & * & milk & $\mathrm{C}$ \\
\hline 9 & $6.54^{\dagger}$ & 28 & milk & $\mathrm{C}$ \\
\hline 10 & $6.48^{\dagger}$ & 14 & minas cheese & $\mathrm{D}$ \\
\hline 11 & $6.48^{\dagger}$ & 12 & minas cheese & $\mathrm{D}$ \\
\hline 12 & $6.43^{\dagger}$ & 10 & minas cheese & $\mathrm{D}$ \\
\hline 13 & 5.40 & 10 & minas cheese & $\mathrm{E}$ \\
\hline 14 & 4.86 & 7 & minas cheese & $\mathrm{E}$ \\
\hline 15 & 4.76 & 4 & minas cheese & $\mathrm{E}$ \\
\hline 16 & $6.48^{\dagger}$ & 15 & minas cheese & $\mathrm{F}$ \\
\hline 17 & 4.99 & 6 & minas cheese & $\mathrm{F}$ \\
\hline 18 & 4.40 & 12 & minas cheese & $\mathrm{F}$ \\
\hline 19 & $<2.00$ & * & yogurt & G \\
\hline 20 & 4.32 & 12 & yogurt & G \\
\hline 21 & 3.72 & 7 & yogurt & G \\
\hline 22 & 4.61 & 3 & yogurt & $\mathrm{H}$ \\
\hline 23 & $<2.00$ & * & Yogurt & $\mathrm{H}$ \\
\hline 24 & 3.86 & 7 & yogurt & $\mathrm{H}$ \\
\hline 25 & 3.49 & 3 & yogurt & I \\
\hline 26 & $<2.00$ & * & Yogurt & I \\
\hline 27 & 3.91 & 7 & yogurt & I \\
\hline
\end{tabular}

${ }^{\dagger}$ Samples with a count $\geq 6 \log$ UFC; ${ }^{\star}$ No microbial growth.

bacteria/g). These results clearly indicate failures in good milking practices, storage, and processing of milk.

\subsection{Identification of psychotropic bacteria}

From the 27 analyzed samples, 210 psychrotrophic microorganisms were isolated, such as bacteria $(n=176)$ and yeasts $(\mathrm{n}=34)$. Bacteria were classified in Gram-positive $(\mathrm{n}=77)$ and Gram-negative $(n=99)$. Table 2 shows the species of Gramnegative bacteria that were identified. In summary, a total of 11 different genera were found: Acinetobacter $[\mathrm{n}=39]$, Aeromonas $[\mathrm{n}=2]$, Bulkhoderia $[\mathrm{n}=23]$, Citrobacter $[\mathrm{n}=1]$, Enterobacter $[\mathrm{n}=6]$, Escherichia $[\mathrm{n}=1]$, Kluyvera $[\mathrm{n}=1]$, Ochrobactrum $[\mathrm{n}=1]$, Pasteurella $[\mathrm{n}=2]$, Proteus $[\mathrm{n}=1]$, Pseudomonas $[\mathrm{n}=2]$. Acinetobacter (39\%) and Bulkhoderia (23\%) were the genera with the highest incidence. The incidence of other genera varied between 1 and $10 \%$.
Table 2. Identification of Gram-negative psychotrophic bacteria isolated from Brazilian organic dairy products.

\begin{tabular}{lcr}
\hline Identification & NI & $\%$ \\
\hline Acinetobacter baumannii/calcoaceticus & 39 & $39.4 \%$ \\
Aeromonas hydrophila & 2 & $2.0 \%$ \\
Burkholderia pseudomallei & 23 & $23.2 \%$ \\
Citrobacter freundii & 1 & $1.0 \%$ \\
Enterobacter amnigenus 1 & 1 & $1.0 \%$ \\
Enterobacter cloacae & 1 & $1.0 \%$ \\
Enterobacter gergoviae & 1 & $1.0 \%$ \\
Enterobacter sakazakii & 3 & $3.0 \%$ \\
Escherichia coli 1 & 1 & $1.0 \%$ \\
Escherichia coli 2 & 1 & $1.0 \%$ \\
Hafnia alvei & 10 & $10.1 \%$ \\
Kluyvera cryocrescens & 1 & $1.0 \%$ \\
Ochrobactrum anthropi & 1 & $1.0 \%$ \\
Pasteurella aerogenes & 2 & $2.0 \%$ \\
Proteus mirabilis & 1 & $1.0 \%$ \\
Pseudomonas aeruginosa & 6 & $6.1 \%$ \\
Pseudomonas putida & 1 & $1.0 \%$ \\
Serratia liquefaciens & 1 & $1.0 \%$ \\
Serratia marcescens & 1 & $1.0 \%$ \\
Shigella dysenteriae sorogrupo a & 2 & $2.0 \%$ \\
Total & 99 & $100 \%$ \\
\hline
\end{tabular}

$\mathrm{NI}=$ number of Gram-negative isolates of each species found in the 27 analyzed samples. $\%=$ percentage representation in relation to the number of total Gram-negative isolates.

Table 3 presents the Gram-negative bacteria in Brazilian organic dairy products (milk, minas cheese and yogurt). The genus Acinetobacter was the most incident (51.7\%) genus in pasteurized whole milk, followed by the genus Hafnia (13.8\%) and Burkholderia (12.1\%). Similarly, Burkholderia (23.1\%) was the most incident genus in yogurts, whereas two Gram-negative isolates, one belonging to the genus Enterobacter and another of the genus Hafnia were detected. The lower incidence of microorganisms in yogurts is related to the low $\mathrm{pH}$ and increased acidity, which compromise the survival of deteriorating and pathogenic micro-organisms. In addition, there is competition for nutrients between the starter culture micro-organisms and the other micro-organisms present (Batista et al., 2017; Sperry et al., 2018).

Pseudomonas, Aeromonas, Hafnia, Acinetobacter, and Serratia are the most commonly found genera in raw refrigerated milk (Mallet et al., 2012; Machado et al., 2017, Ramos \& Nascimento, 2020). Their presence in processed organic dairy products may be related to the survival of these micro-organisms through conventional heat treatments applied or even incidence of post-pasteurization contamination.

Acinetobacter is a complex genus whose micro-organisms have been associated with nosocomial infections, predominantly aspiration pneumonia, catheter-associated bacteremia, soft tissue, and urinary tract infections (Wong et al., 2017). There are more than 50 species belonging to this genus; however, Acinetobacter baumannii, Acinetobacter calcoaceticus, and Acinetobacter iwoffi $i$ are the most frequent species associated with infections (Wong et al., 2017). 
Table 3. Gram-negative bacteria (\%) in Brazilian organic dairy products (milk, minas cheese and yogurt).

\begin{tabular}{lc}
\hline Species & $\%$ \\
\hline Organic Milk & \\
Acinetobacter baumannii/calcoaceticus & $51.7 \%$ \\
Aeromonas hydrophila & $1.7 \%$ \\
Burkholderia pseudomallei & $12.1 \%$ \\
Enterobacter gergoviae & $1.7 \%$ \\
Enterobacter sakazakii & $3.4 \%$ \\
Hafnia alvei & $13.8 \%$ \\
Kluyvera cryocrescens & $1.7 \%$ \\
Proteus mirabilis & $1.7 \%$ \\
Pseudomonas aeruginosa & $5.2 \%$ \\
Serratia liquefaciens & $1.7 \%$ \\
Serratia marcescens & $1.7 \%$ \\
Shigella dysenteriae sorogrupo a & $3.4 \%$ \\
Organic minas cheese & \\
Acinetobacter baumannii/calcoaceticus & \\
Aeromonas hydrophila & $23.1 \%$ \\
Burkholderia pseudomallei & $2.6 \%$ \\
Citrobacter freundii & $41.0 \%$ \\
Enterobacter amnigenus 1 & $2.6 \%$ \\
Enterobacter sakazakii & $2.6 \%$ \\
Escherichia coli 1 & $2.6 \%$ \\
Escherichia coli 2 & $2.6 \%$ \\
Hafnia alvei & $2.6 \%$ \\
Ochrobactrum anthropi & $2.6 \%$ \\
Pasteurella aerogenes & $2.6 \%$ \\
Pseudomonas aeruginosa & $5.1 \%$ \\
Pseudomonas putida & $7.7 \%$ \\
Organic yogurt & $2.6 \%$ \\
Enterobacter cloacae & \\
Hafnia alvei & $50.0 \%$ \\
& $50.0 \%$ \\
\hline
\end{tabular}

In routine diagnosis, $A$. baumannii, $A$. pittii, $A$. nosocomialis and $A$. calcoaceticus strains are difficult to be accurately differentiated, since they are highly similar in their phenotypic and biochemical properties and show a close relationship in DNA-DNA hybridization (DDH) studies. Therefore, these strains are commonly grouped in the so-called Acinetobacter baumannii/calcoaceticus complex (Cho et al., 2018). This group presents recognized antibiotic resistance phenotype; therefore, contaminated foods constitute a risk to children and individuals with compromised immunity (Wong et al., 2017). Acinetobacter baumannii/calcoaceticus were found in 39\% of the organic dairy isolates evaluated in this study.

The presence of the Burkholderia pseudomallei in Minas Frescal cheese and milk samples $(23.23 \%)$ is of concern since this bacterium is a foodborne pathogen associated with melioidosis, a serious and commonly fatal disease that affects humans and animals. In humans, it can trigger skin infections, septicemia, and pneumonia (Titball et al., 2017). According to Limmathurotsakul \& Peacock (2011), there are 165,000 cases of melioidosis per year, from which 89,000 deaths occur. In this view, the number of deaths related to melioidosis is comparable to mortality caused by measles $(95,600$ per year) and higher than the death rate from leptospirosis $(50,000$ per year) or dengue (9,100-12,500 per year). Pathogenic microorganisms are commonly found in cheeses (Mendonça et al., 2019; CunhaNeto et al., 2020) and milk (Mullan, 2019).

Hafnia alvei belongs to the Enterobacteriaceae family and is related to uncommon infections. It is considered an opportunistic pathogen that causes invasive infections in debilitated elderly with underlying diseases (Baral et al., 2018). Baral et al. (2018) reported a case of bacteremia caused by Hafnia alvei resulting in bronchopneumonia in an 11-month-old child. Díaz et al. (2017) presented a clinical case of a 40 -year-old patient with no pathological history affected by a prolonged febrile state. The patient was diagnosed with subacute bacterial endocarditis in the native mitral valve caused by Hafnia alvei. This micro-organism was found in $10.10 \%$ of the organic dairy isolates evaluated in the present study.

Pseudomonas species are strongly associated with deterioration of milk and other daisy foods (Baglinière et al., 2017). Because it is widely distributed in nature, such as in water and soil, it easily contaminates animal udder and milking equipment and has been used as a model to assess the effects of psychrotrophic bacteria on milk (Oliveira et al. 2015, Machado et al., 2017). Serratia species, such as Serratia liquefaciens and Serratia marcescens, are also known to deteriorate raw milk, being able to produce thermoresistant enzymes and biofilms (Baglinière et al., 2017). Serratia and Pseudomonas species are post pasteurization contaminants and are involved in the deterioration of pasteurized dairy products. Therefore, these micro-organisms should be reduced to increase the shelf life of dairy foods (Van Tassell et al., 2012).

Enterobacteriaceae species (Citrobacter freundii, Enterobacter amnigenus 1, Enterobacter cloacae, Enterobacter gergoviae, Enterobacter sakazakii, Escherichia coli 1, Escherichia coli 2, Proteus mirabilis and Shigella dysenteriae serogroup a) were found in organic milk isolates $(<3 \%)$. Contamination of raw milk with Enterobacteriaceae species may be associated with mastitis, animal feces, or with contamination of milking equipment (VásquezJaramillo et al., 2017). The major concern is the presence of Enterobacteriaceae bacteria that produce extended-spectrum beta-lactamase, which reduce the efficacy of a wide range of beta-lactam antibiotics, such as third-generation cephalosporins and monolactams (Vásquez-Jaramillo et al., 2017).

Shigella spp. can infect humans and non-human primates and is a major cause of dysentery, affecting more than 80 million people and causing more than 700,000 deaths each year worldwide. The infectious dose may be as low as 10 organisms, making Shigella a food-borne pathogen of global importance and a significant risk to public health (Weis et al., 2017). During pregnancy, women are more susceptible to listeriosis, which can result in premature labor, spontaneous abortion, chorioamnionitis, and maternal/neonatal sepsis (Bhaskar \& Chaudhury, 2018). Shigella dysenteriae serogroup a was found in $2.02 \%$ of the organic dairy isolates from this study.

Aeromonas hydrophila is an aquatic micro-organism of medical importance that was originally isolated from frogs. Aeromoniasis can be caused by A. hydrophila, A. caviae, and A. sobria. Among these species, $A$. hydrophila is an emerging 
bacterial zoonotic pathogen transmitted by food, which can cause disease in immunocompetent persons as well as immunocompromised persons, such as patients suffering from carcinoma, leukemia, and HIV (Pal, 2018). Aeromonas hydrophila was found in $2.02 \%$ of the organic dairy isolates from this study.

The profile of Gram-negative bacteria in organic dairy products indicated the presence of several bacteria that could have a negative impact on human health. Some species were found in high levels (Acinetobacter baumannii, Acinetobacter calcoaceticus, Burkholderia pseudomallei, and Hafnia alvei). Moreover, some bacteria (Pseudomonas, Serratia liquefaciens, and Serratia marcescens) affect the product quality and decrease the shelf life of dairy foods. Finally, some micro-organisms (Shigella), although present in a few isolates, deserve attention for the potential deleterious effects.

\subsection{Evaluation of the production of extracellular enzymes}

Figure 1 shows data on the Gram-negative bacteria that produced the protease, lecithinase, and lipase deteriorating enzymes.

Eighteen (18.2\%) of the 99 isolates of Gram-negative bacteria did not produce any of the enzymes analyzed. On the other hand, $36(36.4 \%)$ produced proteases, 41 (41.4\%) produced lecithinases, and only $4(4 \%)$ produced lipases. Thirty-six $(44 \%)$ of the total number of isolates with enzyme-producing capacity (81) produced two types of enzymes and only one $(1.23 \%)$ produced the three enzymes evaluated in the study condition. The species that produced two enzymes are Acinetobacter baumanniil calcoaceticus and Burkholderia pseudomallei, isolated from pasteurized whole milk and Minas Frescal cheese. Acinetobacter baumannii/calcoaceticus was the species with the greatest capacity to produce lecithinase and Burkholderia pseudomallei was the species with the greatest capacity to produce protease. In fact, Gauthier et al. (2000) reported that more than $90 \%$ of Burkholderia pseudomallei isolates from humans were able to produce lecithinase, protease, and lipase.

Pseudomonas and Acinetobacter were able to produce lipase, corroborating a previous study (Javed et al., 2018). Although these genera are also associated with protease production (Marchand et al., 2009), the refrigeration temperature leads to a higher production of lipolytic enzymes (Nörnberg et al., 2010).

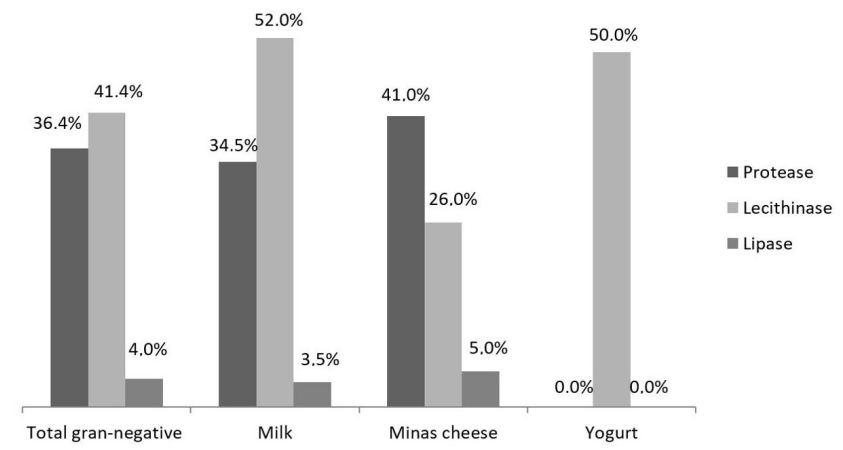

Figure 1. Gram-negative bacteria and Gram-negative bacteria (\%) in organic Brazilian dairy foods (milk, minas cheese and yogurt samples) that produced protease, lecithinase and lipase deteriorating enzymes.
The results indicate that the psychrotrophic bacteria isolated from organic milk and other dairy foods showed high production capacity of enzymes (proteases, lecithins, and lipases), which may alter the sensory, nutritional, and technological characteristics of the products (Machado et al., 2017), resulting in large economic losses for producers and industries (Samarzija et al., 2012). In pasteurized whole milk there was a higher incidence of lecithin producing isolates (52\%), followed by proteases $(34.5 \%)$, and lipases (3.5\%). In Minas Frescal cheese, there was a higher incidence of protease isolates (34.5\%), followed by lecithinase (26\%), and lipase (5\%) producers. Finally, only lecithinase producers $(50 \%)$ were isolated from yogurts. Overall, the type of processing to which the milk is subjected and the process conditions influence the type of micro-organism found and, consequently, the type of enzymes produced.

Thermoresistant proteases present in milk and dairy products can act in the hydrolysis of several types of casein resulting in color changes, with development of grayish coloration. In addition, during cheese processing, proteases increase the destabilization of casein and compromise micelles coagulation, resulting in cheeses with lower consistency and yield (Decimo et al., 2014).

Phospholipases and lecithinases can act on the membranes of milk fat globules, causing rupture and exposing the triacylglycerides to lipases (Koka \& Weimer, 2001). Lipases catalyze the hydrolysis of triacylglycerides and lead to the formation of astringent rancid and soap flavors (De Jonghe et al., 2011). Although the prevalence of lipase-producing bacteria was low in the selected organic products (0-5\%), lipolytic degradation causes the first changes in the flavors and odors of the products by the release of free fatty acids. These alterations affect the sensory acceptability of the product because the released short chain free fatty acids are the main cause of rancidity.

All these changes lead to product rejection by consumers and reduce its shelf life. To avoid economic losses and to obtain high-quality dairy foods, it is essential to avoid the presence and multiplication of psychrotrophic bacteria by adopting GMP at all stages of production, to reduce refrigerated storage periods and adoption of appropriate thermal treatments. The heating process easily destroys psychrotrophic bacteria, but the lipases, proteases, and lecithinases remain active in the processed product (Nörnberg et al., 2009). Because of thermal resistance, the enzymes can maintain 30 to $100 \%$ of their activity after the thermal treatments to which milk and dairy products are submitted (Samaržija et al., 2012).

Although there are few reports on the activity of lipases and lecithinases produced by psychrotrophic bacteria, they are essential for the establishment of control strategies to improve the quality, stability, and shelf life of dairy products (Decimo et al., 2014). Although these enzymes studied are associated with the deterioration and reduction of shelf life, they may be used for the development of aroma and texture of cheeses during maturation time (Jooyandeh et al., 2009; Tavano, 2013).

\subsection{Biofilm-producing capacity}

Gram-negative bacterial isolates were classified as non, low, medium, and high biofilm formers (Figure 2). The results 


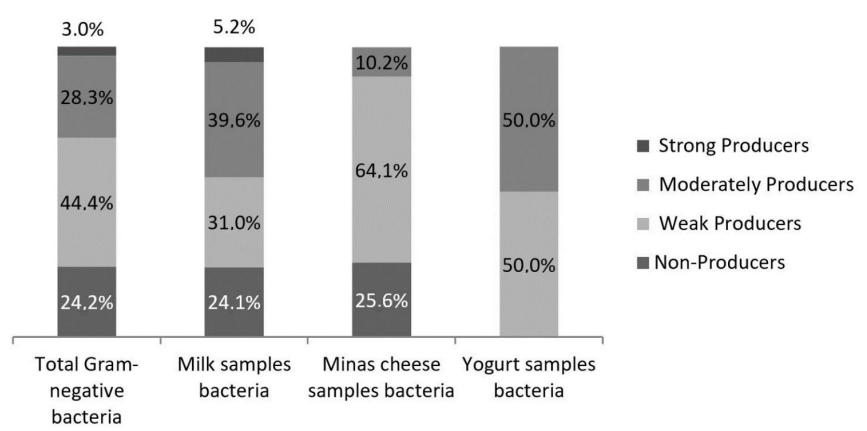

Figure 2. Classification of total psychrotrophic bacteria and psychrotrophic bacteria (\%) in organic Brazilian dairy foods (milk, minas cheese and yogurt samples) related to their capacity of biofilm production.

showed that $68(68.7 \%)$ of the Gram-negative bacteria isolates were non-producers or low biofilm former, 28 (28.3\%) were medium biofilm formers and only 3 (3.0\%) were high biofilm producers.

Biofilms can be characterized as an aggregation of bacteria, algae, fungi and protozoa enclosed in a matrix consisting of a mixture of polymeric compounds, primarily polysaccharides, generally referred to as extracellular polymeric substance (Coughlan et al., 2016). Many psychrotrophic bacteria secrete exopolysaccharides to form biofilms. These substances facilitate the adhesion and aggregation of the bacteria to the surfaces and, when they adhere irreversibly, biofilm formation is initiated (Marchand et al., 2012; Coughlan et al., 2016, Alonso \& Kabuki, 2019). Most of the bacteria found in the organic dairy products were classified as non or low biofilm producers (68.7\%). However, it is important to note that bacteria that do not produce biofilms can adhere to matrices produced by other bacteria.

A prevalence of non or low biofilm producers (55.1 and $89.7 \%$, respectively) was observed in pasteurized whole milk and in Minas Frescal cheeses. In yogurts, only low (50\%) and medium biofilm producers (50\%) were found. The results indicate that the type of processing and the type of processed dairy food influence the biofil-producing ability of micro-organisms. In fact, other factors such as temperature, $\mathrm{pH}$, and nutrient availability influence the formation of biofilms (Shi \& Zhu, 2009). The biofilm formation capacity of distinct bacteria differs according to species, genus, and strain. Accordingly, the intensity of the biofilm production varies according to the environment in a way that the same bacterium may produce biofilm according to the medium (Srey et al., 2013).

Bacterial biofilms make bacteria less susceptible to the antimicrobial agents, more resistant to sanitation, environmental changes, and dehydration/dissection (Coughlan et al., 2016; Bayoumi et al., 2012; Bernbom, Vogel \& Gram, 2011).

Because of the protection offered by this matrix, many chemical sanitizers are inefficient in the removal of most bacteria, since these products are not well diffused in the matrix (Islam et al., 2014; Singhal et al., 2011). Therefore, the sanitization of equipment, utensils, and surfaces must be correctly executed as the presence of nutrients facilitates the microbial adhesion and the beginning of biofilm formation. The configuration of the equipment within the production line should also be checked, with special attention to the presence of cracks, valves and joints that hinders the sanitization operations and favors the formation of biofilms (Cleto et al., 2012). In the case of milks and processed dairy products, biofilms are a major source of re-contamination (Marchand et al., 2012; Coughlan et al., 2016). Pseudomonas aeruginosa can form biofilms on a variety of surfaces (Wu et al., 2016; Flemming \& Wingender, 2010). According to Cleto et al. (2012) and Mangalea et al. (2017), Serratia species and Burkholderia pseudomallei are known to produce of biofilms.

Overall, our findings suggest the quantification of psychrotrophic bacteria in milk should be considered a mandatory analysis as it directly influences the microbiological, physicochemical, and sensory quality of dairy products. Indeed, this is the first study that profiles Gram-negative bacteria in Brazilian organic dairy products. The manufacture of organic dairy products with adequate microbiological characteristics, raw materials must be obtained by means of strictly controlled good manufacturing practices, correct sanitation techniques and by applying appropriate heat treatments, thus reducing the presence of these micro-organisms. In addition to safety and quality, these foods must be prepared in accordance with organic standards and regulations, in order to meet the consumer's demand and expectations for these differentiated products. To the best of our knowledge, this is the first study that reveals the complete profile of Gram-negative psychrotrophic bacteria present in organic milk and dairy products and their ability to produce enzymes and biofilms.

\section{Conclusion}

Organic dairy products presented increased psychrotrophic counts indicating problems in the microbiological quality of the products, suggesting there are problems related to the handling these products, resulting in high counts of psychrotrophic bacteria with the capacity to produce deteriorating enzymes and, to a lesser extent, the formation of biofilms.

\section{Acknowledgements}

The authors would like to thank CNPQ, CAPES, FAPERJ and IFRJ for the financial support.

\section{References}

Alonso, V. P., \& Kabuki, D. Y. (2019). Formation and dispersal of biofilms in dairy substrates. International Journal of Dairy Technology, 72, 472-478. http://dx.doi.org/10.1111/1471-0307.12587.

Baglinière, F., Salgado, R. L., Salgado, C. A., \& Vanetti, M. C. D. (2017). Biochemical characterization of an extracellular heat-stable protease from Serratia liquefaciens isolated from raw milk. Journal of Food Science, 82(4), 952-959. http://dx.doi.org/10.1111/1750-3841.13660. PMid:28222216.

Baral, N., Nayak, N., Shrestha, R., Parajuli, R., Hamal, D., Bhatta, D. R., \& Gokhale, S. (2018). Hafnia alvei bacteremia following bronchopneumonia in an eleven month old child: a case report from a tertiary care hospital in Nepal. International Journal of Advancement in Life Sciences Research, 1(2), 20-25. http://dx.doi. org/10.31632/ijalsr.2018v01i02.004. 
Bates, J. L., \& Liu, P. V. (1963). Complementation of lecithinase activities by closely related pseudomonads: its taxonomic implication. Journal of Bacteriology, 86(3), 585-592. http://dx.doi.org/10.1128/JB.86.3.585592.1963. PMid:14066442.

Batista, A. L. D., Silva, R., Cappato, L. P., Ferreira, M. V. S., Nascimento, K. O., Schmiele, M., Esmerino, E. A., Balthazar, C. F., Silva, H. L. A., Moraes, J., Pimentel, T. C., Freitas, M. Q., Raices, R. S. L., Silva, M. C., \& Cruz, A. G. (2017). Developing a synbiotic fermented milk using probiotic bacteria and organic green banana flour. Journal of Functional Foods, 38, 242-250. http://dx.doi.org/10.1016/j. jff.2017.09.037.

Bayoumi, M. A., Kamal, R. M., Abd El Aal, S. F., \& Awad, E. I. (2012). Assessment of a regulatory sanitization process in Egyptian dairy plants in regard to the adherence of some food-borne pathogens and their biofilms. International Journal of Food Microbiology, 158(3), 225-231. http://dx.doi.org/10.1016/j.ijfoodmicro.2012.07.021. PMid:22884171.

Bee Lian, S. B., Safari, M., \& Mansori, S. (2016). The Marketing Stimuli Factors Influencing Consumer's Attitudes to Purchase Organic Food. International Journal of Business and Management, 11(10), 109-119. http://dx.doi.org/10.5539/ijbm.v11n10p109.

Bernbom, N., Vogel, B. F., \& Gram, L. (2011). Listeria monocytogenes survival of UV-C radiation is enhanced by presence of sodium chloride, organic food material and by bacterial biofilm formation. International Journal of Food Microbiology, 147(1), 69-73. http:// dx.doi.org/10.1016/j.ijfoodmicro.2011.03.009. PMid:21463911.

Bhaskar, A. V., \& Chaudhury, K. (2018). Drinking water contaminants: maternal and fetal health risks. In Sustainable Solution with Appropriate Technological Development and Innovation (Swadin) Conference (pp. 28-33). West Lafayette: Purde University. Retrieved from https://docs. lib.purdue.edu/cgi/viewcontent.cgi? article $=1015 \&$ context $=$ swadin

Cho, G. S., Li, B., Rostalsky, A., Fiedler, G., Rösch, N., Igbinosa, E., Kabisch, J., Bockelmann, W., Hammer, P., Huys, G., \& Franz, C. M. A. P. (2018). Diversity and antibiotic susceptibility of acinetobacter strains from milk powder produced in Germany. Frontiers in Microbiology, 9, 536. http://dx.doi.org/10.3389/fmicb.2018.00536. PMid:29636733.

Cleto, S., Matos, S., Kluskens, L., \& Vieira, M. J. (2012). Characterization of contaminants from a sanitized milk processing plant. PLoS One, 7(6), e40189. http://dx.doi.org/10.1371/journal.pone.0040189. PMid:22761957.

Coughlan, L. M., Cotter, P. D., Hill, C., \& Alvarez-Ordóñez, A. (2016). New weapons to fight old enemies: novel strategies for the (bio) control of bacterial biofilms in the food industry. Frontiers in Microbiology, 7(1641), 1-21. http://dx.doi.org/10.3389/fmicb.2016.01641. PMid:27803696.

Cunha-Neto, A., Carvalho, L. A., Castro, V. S., Barcelos, F. G., Carvalho, R. C. T., Rodrigues, D. P., Conte-Junior, C. A., \& Figueiredo, E. E. S. (2020). Salmonella Anatum, S. Infantis and S. Schwarzengrund in Brazilian Cheeses: occurrence and antibiotic resistance profiles. International Journal of Dairy Technology, 73(1), 296-300. http:// dx.doi.org/10.1111/1471-0307.12636.

De Jonghe, V., Coorevits, A., Van Hoorde, K., Messens, W., Van Landschoot, A., De Vos, P., \& Heyndrickx, M. (2011). Influence of storage conditions on the growth of Pseudomonas species in refrigerated raw milk. Applied and Environmental Microbiology, 77(2), 460-470. http://dx.doi.org/10.1128/AEM.00521-10. PMid:21115713.

Decimo, M., Morandi, S., Silvetti, T., \& Brasca, M. (2014). Characterization of gram-negative psychrotrophic bacteria isolated from Italian bulk tank milk. Journal of Food Science, 79(10), M2081-M2090. http:// dx.doi.org/10.1111/1750-3841.12645. PMid:25224662.
Díaz, T. S., Jiménez, J. V., Candelario, R. V., \& Piedra, Y. A. (2017). Infective endocarditis in native mitral valve by Hafnia alvei. Revista Cubana de Medicina Militar, 47(1), 80-87.

Dogan, B., \& Boor, K. J. (2003). Genetic diversity and spoilage potentials among Pseudomonas spp. isolated from fluid milk products and dairy processing plants. Applied and Environmental Microbiology, 69(1), 130138. http://dx.doi.org/10.1128/AEM.69.1.130-138.2003. PMid:12513987.

Dolgopolova, I., \& Roosen, J. (2018). Competitive niche in milk pricing: Analyzing price dynamics of GMO-free, organic, and conventional milk in Germany during 2009-2010. Food Policy, 78, 51-57. http:// dx.doi.org/10.1016/j.foodpol.2018.02.006.

Flemming, H. C., \& Wingender, J. (2010). The biofilm matrix. Nature Reviews. Microbiology, 8(9), 623-633. http://dx.doi.org/10.1038/ nrmicro2415. PMid:20676145.

Gauthier, Y. P., Thibault, F. M., Paucod, J. C., \& Vidal, D. R. (2000). Protease production by Burkholderia pseudomallei and virulence in mice. Acta Tropica, 74(2-3), 215-220. http://dx.doi.org/10.1016/ S0001-706X(99)00073-X. PMid:10674652.

Hahne, J., Isele, D., Berning, J., \& Lipski, A. (2019). The contribution of fast growing, psychrotrophic microorganisms on biodiversity of refrigerated raw cow's milk with high bacterial counts and their food spoilage potential. Food Microbiology, 79, 11-19. http://dx.doi. org/10.1016/j.fm.2018.10.019. PMid:30621865.

Hanamant, P. S., \& Bansilal, G. M. (2013). Lipolytic psychrotrophic gram positive cocci in milk and fermented milk products. Journal of Environmental Research and Development, 8(2), 273.

Heckman, J. R. (2019). Securing fresh food from fertile soil, challenges to the organic and raw milk movements. Renewable Agriculture and Food Systems, 34(5), 472-485. http://dx.doi.org/10.1017/S1742170517000618.

Islam, M. T., Oishi, A., Machida, C., Ogura, A., Kin, S., Honjoh, K. I., \& Miyamoto, T. (2014). Combined effects of selected food additives on adhesion of various foodborne pathogens onto microtiter plate and cabbage leaves. Food Control, 46, 233-241. http://dx.doi.org/10.1016/j. foodcont.2014.05.034.

Javed, S., Azeem, F., Hussain, S., Rasul, I., Siddique, M. H., Riaz, M., Afzal, M., Kouser, A., \& Nadeem, H. (2018). Bacterial lipases: a review on purification and characterization. Progress in Biophysics and Molecular Biology, 132, 23-34. http://dx.doi.org/10.1016/j. pbiomolbio.2017.07.014. PMid:28774751.

Jooyandeh, H., Amarjeet, K., \& Minhas, K. S. (2009). Lipases in dairy industry: a review. Journal of Food Science and Technology, 46, 181-189.

Koka, R. A., \& Weimer, B. C. (2001). Influence of growth conditions on heat-stable phospholipase activity in pseudomonas. The Journal of Dairy Research, 68(1), 109-116. http://dx.doi.org/10.1017/ S0022029900004647. PMid:11289260.

Kouřimská, L., Legarová, V., Panovská, Z., \& Pánek, J. (2014). Quality of cows' milk from organic and conventional farming. Czech Journal of Food Sciences, 32(4), 398-405. http://dx.doi.org/10.17221/510/2012-CJFS.

Limmathurotsakul, D., \& Peacock, S. J. (2011). Melioidosis: a clinical overview. British Medical Bulletin, 99(1), 125-139. http://dx.doi. org/10.1093/bmb/ldr007. PMid:21558159.

Lu, C. D., Gangyi, X., \& Kawas, J. R. (2010). Organic goat production, processing and marketing: Opportunities, challenges and outlook. Small Ruminant Research, 89(2-3), 102-109. http://dx.doi.org/10.1016/j. smallrumres.2009.12.032.

Machado, S. G., Baglinière, F., Marchand, S., Van Coillie, E., Vanetti, M. C. D., De Block, J., \& Heyndrickx, M. (2017). The Biodiversity of the Microbiota Producing Heat-Resistant Enzymes Responsible for Spoilage in Processed Bovine Milk and Dairy Products. Frontiers in Microbiology, 8, 302. http://dx.doi.org/10.3389/fmicb.2017.00302. PMid:28298906. 
Mallet, A., Guéguen, M., Kauffmann, F., Chesneau, C., Sesboué, A., \& Desmasures, N. (2012). Quantitative and qualitative microbial analysis of raw milk reveals substantial diversity influenced by herd management practices. International Dairy Journal, 27(1-2), 13-21. http://dx.doi.org/10.1016/j.idairyj.2012.07.009.

Mangalea, M. R., Plumley, B. A., \& Borlee, B. R. (2017). Nitrate sensing and metabolism inhibit biofilm formation in the opportunistic pathogen Burkholderia pseudomallei by reducing the intracellular concentration of c-di-GMP. Frontiers in Microbiology, 8:1353. http:// dx.doi.org/10.3389/fmicb.2017.01353. PMid:28790983.

Marchand, S., De Block, J., De Jonghe, V., Coorevits, A., Heyndrickx, M., \& Herman, L. (2012). Biofilm formation in milk production and processing environments; influence on milk quality and safety. Comprehensive Reviews in Food Science and Food Safety, 11(2), 133147. http://dx.doi.org/10.1111/j.1541-4337.2011.00183.x.

Marchand, S., Vandriesche, G., Coorevits, A., Coudijzer, K., De Jonghe, V., Dewettinck, K., De Vos, P., Devreese, B., Heyndrickx, M., \& De Block, J. (2009). Heterogeneity of heat-resistant proteases from milk Pseudomonas species. International Journal of Food Microbiology, 133(1-2), 68-77. http://dx.doi.org/10.1016/j.ijfoodmicro.2009.04.027. PMid:19481283.

Mastromatteo, M., Danza, A., Conte, A., Muratore, G., \& Del Nobile, M. A. (2010). Shelf life of ready to use peeled shrimps as affected by thymol essential oil and modified atmosphere packaging. International Journal of Food Microbiology, 144(2), 250-256. http:// dx.doi.org/10.1016/j.ijfoodmicro.2010.10.002. PMid:21047694.

Mendonça, J. F. M., Vieira, F. O., Fonseca, I., Ribeiro, J. B., Arcuri, E. F., Borges, M. F., Borges, C. A. V., Sá, J. F. O., \& Martins, M. F. (2019). Detection of Viable Salmonella Typhimurium and Staphylococcus aureus in Coalho Cheese by Real-Time PCR. Food Science and Technology (Campinas), 39(Suppl 2), 690-696. http://dx.doi.org/10.1590/fst.29318.

Mullan, W. M. A. (2019). Are we closer to understanding why viable cells of Mycobacterium avium subsp. paratuberculosis are still being reported in pasteurised milk? International Journal of Dairy Technology, 72(3), 332-344. http://dx.doi.org/10.1111/1471-0307.12617.

Nörnberg, M. F. B. L., Tondo, E. C., \& Brandelli, A. (2009). Psychrotrophic bacteria and proteolytic activity in refrigerated raw milk. Acta Scientiae Veterinariae, 37, 157-163.

Nörnberg, M. F., Friedrich, R. S., Weiss, R. D., Tondo, E. C., \& Brandelli, A. (2010). Proteolytic activity among psychrotrophic bacteria isolated from refrigerated raw milk. International Journal of Dairy Technology, 63(1), 41-46. http://dx.doi.org/10.1111/j.1471-0307.2009.00542.x.

Oliveira, G. B., Favarin, L., Luchese, R. H., \& McIntosh, D. (2015). Psychrotrophic bacteria in milk: How much do we really know? Brazilian Journal of Microbiology, 46(2), 313-321. http://dx.doi. org/10.1590/S1517-838246220130963. PMid:26273245.

Pal, M. (2018). Is aeromonas hydrophila a potential pathogen of food safety concern? Journal of Food Microbiology, 2, 9-10.

Ramos, G. L. D. P. A., \& Nascimento, J. D. S. (2020). Pseudomonas SP. in uninspected raw goat's milk in Rio de Janeiro, Brazil. Food Science and Technology (Campinas), 40(Suppl. 2), 605-611. http:// dx.doi.org/10.1590/fst.21719.

Samarzija, D., Zamberlin, S., \& Pogacic, T. (2012). Psychrotrophic bacteria and milk and dairy products quality. Mljekarstvo, 62(2), 77-95.

Schwendel, B. H., Wester, T. J., Morel, P. C., Tavendale, M. H., Deadman, C., Shadbolt, N. M., \& Otter, D. E. (2015). Invited review: organic and conventionally produced milk-an evaluation of factors influencing milk composition. Journal of Dairy Science, 98(2), 721-746. http:// dx.doi.org/10.3168/jds.2014-8389. PMid:25497795.
Shi, X., \& Zhu, X. (2009). Biofilm formation and food safety in food industries. Trends in Food Science \& Technology, 20(9), 407-413. http://dx.doi.org/10.1016/j.tifs.2009.01.054.

Singhal, D., Foreman, A., Jervis-Bardy, J., \& Wormald, P. J. (2011). Staphylococcus aureus biofilms: Nemesis of endoscopic sinus surgery. The Laryngoscope, 121(7), 1578-1583. http://dx.doi.org/10.1002/ lary.21805. PMid:21647904.

Sperry, M. F., Silva, H. L. A., Balthazar, C. F., Esmerino, E. A., Verruck, S., Prudencio, E. S., Neto, R. P. C., Tavares, M. I. B., Peixoto, J. C., Nazzaro, F., Rocha, R. S., Moraes, J., Gomes, A. S. G., Raices, R. S. L., Silva, M. C., Granato, D., Pimentel, T. C., Freitas, M. Q., \& Cruz, A. G. (2018). Probiotic Minas Frescal cheese added with L. casei 01: Physicochemical and bioactivity characterization and effects on hematological/biochemical parameters of hypertensive overweighted women-A randomized double-blind pilot trial. Journal of Functional Foods, 45, 435-443. http://dx.doi.org/10.1016/j.jff.2018.04.015.

Srey, S., Jahid, I. K., \& Ha, S. D. (2013). Biofilm formation in food industries: A food safety concern. Food Control, 31(2), 572-585. http://dx.doi.org/10.1016/j.foodcont.2012.12.001.

Stepanovic, S., Vukovic, D., Dakic, I., Savic, B., \& Svabic-Vlahovic, M. A. (2000). Modified microtiter-plate test for quantification of staphylococcal biofilm formation. Journal of Microbiological Methods, 40(2), 175-179. http://dx.doi.org/10.1016/S0167-7012(00)00122-6. PMid:10699673.

Tavano, O. L. (2013). Protein hydrolysis using peptidases: an important tool for food biotechnology. Journal of Molecular Catalysis. B, Enzymatic, 90, 1-11. http://dx.doi.org/10.1016/j.molcatb.2013.01.011.

Titball, R. W., Burtnick, M. N., Bancroft, G. J., \& Brett, P. (2017). Burkholderia pseudomallei and Burkholderia mallei vaccines: Are we close to clinical trials? Vaccine, 35(44), 5981-5989. http://dx.doi. org/10.1016/j.vaccine.2017.03.022. PMid:28336210.

Van Tassell, J. A., Martin, N. H., Murphy, S. C., Wiedmann, M., Boor, K. J., \& Ivy, R. A. (2012). Evaluation of Various selective media for the detection of Pseudomonas species in pasteurized milk. Journal of Dairy Science, 95(3), 1568-1574. http://dx.doi.org/10.3168/ jds.2011-4958. PMid:22365238.

Vásquez-Jaramillo, L., Ramírez, N. F., Akineden, Ö., \& Fernández-Silva, J. A. (2017). Presence of extended-spectrum beta-lactamase (ESBL)producing Enterobacteriaceae in bulk-tank milk of bovine dairy farms in Antioquia, Colombia. Revista Colombiana de Ciencias Pecuarias, 30(2), 85-100. http://dx.doi.org/10.17533/udea.rccp.v30n2a01.

Weis, A. M., Gilpin, B., Huang, B. C., Kong, N., Chen, P., \& Weimer, B. C. (2017). Shigella draft genome sequences: resources for food safety and public health. Genome Announcements, 5(16), e0017617. http://dx.doi.org/10.1128/genomeA.00176-17. PMid:28428292.

Willer. H. \& Kilcher, L. (2011). The world of organic agriculture. Statistics and emerging trends 2011 (FiBL-IFOAM Report). Switzerland: FiBL.

Wong, D., Nielsen, T. B., Bonomo, R. A., Pantapalangkoor, P., Luna, B., \& Spellberg, B. (2017). Clinical and pathophysiological overview of Acinetobacter infections: a century of challenges. Clinical Microbiology Reviews, 30(1), 409-447. http://dx.doi.org/10.1128/CMR.00058-16. PMid:27974412.

Wu, S., Liu, G., Jin, W., Xiu, P., \& Sun, C. (2016). Antibiofilm and anti-infection of a marine bacterial Exopolysaccharide Against Pseudomonas aeruginosa. Frontiers in Microbiology, 7, 102. http:// dx.doi.org/10.3389/fmicb.2016.00102. PMid:26903981. 